\title{
Dariusz Tabor
}

\section{GESTURE AS THE EXPRESION OF THE PASCAL MYSTERY IN THE CENTRAL EUROPEAN MEDIEVAL ART}

The Paschal Mystery is the central reality of the Christianity. This is a series of historical events, presented in the canonical Gospels, in which Jesus from Nazaret was submit to the suffering, death, but was revived and bas ascend 10 the glory. These events was full of meanings and significations. This significations of paschal event has been meditated and analyzed in the Christian text, - in Gospels, in Paul's Letters, but in the sermon of Fathers of the Church. Meliton of Sardes, Orygenes, Pseudo-Hypolite, and others are known as the interpreters of paschal events. The liturgical texts - Exultet and Victimae Paschali explain the profound sense of the Death and the resurrection of Christ.

All these works inspired the iconography. This presentation has to review the some works of art in Central Europeand interpretations their tbeological sense. The gestures will be the key to discovery of meaning.

\section{SON SENDED BY THE GOD FATHER}

A double miniature of the Augustinian Matutinale et vesperale from Zitava shows us the strange situation (fig. 1). God Father in the majesty push by both hands the nude corps of little Jesus bearing the cross ${ }^{1}$. The similar scene is in the capital of the funeral monument of Casmir the IV, king of Poland and the Grad Duke of the Lithuania in the Krakow's cathedral (fig. 2). The adult, Rode Cin who bears the cross is pushed by Father ${ }^{2}$. The contrast between the Micicic $\mathbf{C}$ Father and the poor, nude Christ is remarkable. What means this repen This is the illustration of the mystery of God's plans. God Father Son to the Earth, who have to complete the work of the bumen sarsien

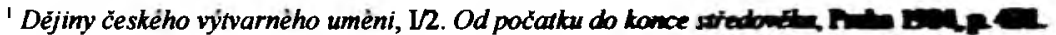

${ }^{2}$ P. Skubiszewski, Rzeźba nagrabna Wita Stwasza, Whrzame 1957 , Stoss und Polen, Nümberg 1983, p. 134.
} 
This concept comes from the letters of saint Paul, but his direct inspiration in Speculum humanae salvationis. This symbolic and prophetic image predict the events of saving works of Christ - Passion, Death, Resurrection and Glory. Therefore it is very important of the Pascal Mystery.

The central reality of this representation is the gesture of two hands of the God Father. This gesture contents decision and order: the Son will be offered in order to save the mankind. Christ Rude and bearing the cross is prepared to the suffering, death and resurrection. This mysterious gesture is the interpretation key of this representation. It let us understand all message of the sending San to the Earth.

\section{VIR DOLORUM - MAN OF SORROW}

Vir Dolorum is the iconographical type of great importance in Central Europe. It represents suffering but living Christ. This isn't an illustration of any event of Passion mentioned in Gospel. Its biblical source is the figure of suffering Servant of YHVH from the Book of Isaiah (Is 53, 1-12). Vir Dolorum is the mystical synthesis of the suffering and glory, of Passion and Resurrection of Christ. A historical representation inspiring the personal devotion reflects the suffering and pain of Savior.

This are two types of gesture - the crossed hands on the chest or on the stomach and ostentatio vulnerum. It shows the different aspects of the devotion and spirituality connected with this representation.

The crossed hands is the very popular gesture. It is the characteristic feature of the dead man deposed in the tomb. It occurs in the funeral contexts ${ }^{3}$. This position of hand derives from the Byzantine representation of dead Christ deposed in the tombstone. The most important example is the inexistent mosaic from Santa Croce in Gerusalemme in Rom represented by the drawing of Israel van Mecke$n^{4}{ }^{4}$. In Bizantium the hands crossed on the chest was the expression of submission and adoration. In the germane art of XIV and XV century this gesture was connected with the image of living but timelessly suffering Christ ${ }^{5}$. In the Byzantine court crossing the hands was the sign of submition. The meaning of this gesture reveals his ambiguity. It is expanded between submission and humility and state of death.

Half figure of Christ with the crossed hands on the stomach who stands in a sarcophagus is engraved in the chalice from Zory in Upper Silesia. This gesture emphasizes the fact of the death of Christ and inspires the emotions of compassion? ${ }^{7}$.

\footnotetext{
${ }^{3} \mathrm{M}$ Barassch. Giotto and the language of gesture, Cambridge, 1987, p. 76-77.

${ }^{4}$ E. Panofs ky, Imago Pietatis:przyczynek do historii typów przedstawieniowych - Mqż Boleści i Maryja Pośredniczka, [in:] E. Panofsky, Średniowiecze, Warszawa 2001, s. 221; Festschrift Max Friedländer, Leipzig 1927, p. 261-308.

${ }^{5}$ Ibidem, p. 241-242.

${ }^{6} \mathrm{M}$. Barasch. Giotto and the language, p. 77.

${ }^{7}$ G. Regulska, Gotyckie zlotnictwo na Slqqsku, Warszawa 2001, il. 66.
} 
The second type of the gesture, ostentatio vulnerum, derives from an image of Speculum Humanae Salvationis, where Christ presents his injures raising the hands to the God Father ${ }^{8}$. Christ stands before his Father as intercessor. The injures are the evidences of his work of salvation.

Vir Dolorum from the retable of Levoca touches his injury of the right side with his right hand and raises the left hand ${ }^{9}$. The same gesture we observe in the half figure of Christ who emerges from sarcophagus in the monstrance from Racibórz (1495) (fig. 3) ${ }^{10}$.

In both representation Christ don't shows his injures to the Father but to the lookers, to the audience. It could be inspired by the Gospel of John: "...venit Jesus et stetit in medio et dicit eis pax vobis et hoc cum dixisset ostendit eis manus et latus..." (John 20, 19-20). Bernard of Clairvaux found in the opened injures of Christ his divinity and his mercy. Saint Gertrude of Helfta contemplated the Passion of Christand the injure of the Christ's side. The contemplation of the suffering Christ was the one of the most significant feature of the medieval spirituality.

What elements of these representation affirms the Paschality? The second type of gesture - ostenesio vulnerum emphasize the importance and the great role of the injure of Christ's side. The Gospel of John mentions the pierced side of Christ, from whom flod water and blood: "...sed unus militum lancea latus eius aperuit et continuo exivit sanguis et aqua..." (John 19,14). The blood and the water flood from his side was understood by Fathers as a sacrament of Baptism and Eucharist. The Man of Sorrows - Vir Dolorum in central Europe was connected with the places of celebration and preservation of Eucharist. This image holds the meaning of Eucharist. Therefore the Pascal Mystery is expressed by the gesture of presentation of the side in jury.

\section{NUCLEUS OF THE NARRATIVE CYCLES}

The narrative cycles of life of Christ had especially ability to express the Pascal Mystery. The images, inspiring by Gospel represent the most significative episodes from life, teaching, passion and glory of Christ. Among many of the representation derivating from the Gospel are the several images, which hold the high density of the paschal character. These are Crucifixion, Descending into hell, and Three women will angel at the tomb. They have the special paschal meaning. Crucifixion is the fulfilments of the work of salvation. Descending into the hell is the illustration of the idea of kenosis - profound humiliation of Christ. The scene of women at the tomb is the testimony of the victory and resurrection.

The analysis and interpretation of the gesture could discover the forgotten meanings, emphasises same aspects of the paschality.

\footnotetext{
${ }^{8}$ B. Panofsky, Imago Pietatis, p. 247-249.

'J. Homolka, Gotická plastika na Slovensku, Brntislava 1972, p. 399.

${ }^{10}$ G. Regulska, Gotyckie zlotnictwo na Ślqsku, il. 127.
} 


\section{A. CRUCIFIXION}

A plate from the bronze gale of Plock (now in Novogrod) represent the crucified Christ between Mary and John (fig. 4). The right hand of Jesus is stretched to his mother. She take his palm carefully. Crucified Christ ist living and conscious". This extraordinary gesture express the intimate relation between mother and son. It could be inspired by the dialog under the cross from Gospelof John: "...mulier ecce filius tuus deinde dicit discipulo ecce mater tua..." (John 19, 26-27). It is possible that this image connect two representation - Crucifixion and Deposition. What is underlined in the meaning of this gesture? The tender, affectionate relation (aspect of the Depositon) or determinated testament from the cross (aspect of the Crucifixion)? The answer is not so light. The majestic figure of living Christ less us declare that Jesus commend to Mary John, her new Son.

The miniature of Crucifixion form Landgrafenpsalter (Stuttgart, Würtembergische Landesbibliothek, H. B. II, fol. 24, 73v.) presents crucified with Mary and John (fig. 5) ${ }^{12}$. Mother of Jesus has the braided palms at her breast. (wronged her hands). John touch is cheek by his right hand .Both gesture are the expression of the pain, hurt and deploration. The same attitudes we observe in the miniature of Crucifixion from Brandemburger Evangelistar (Brandemburg, Domarchive, 50r).

This gestures of Mary and St John are the attitudes towards the death of Christ. Jesus is dead but attached to the cross and exposed in the majestic pose. His mother and his disciples affirm this decisive moment.

The miniature of Crucifixion from the Psalter of Trzebnica (Wrocław, University Library, IF 440, 68r) is very similar to the both described miniature ${ }^{13}$. Mother of Jesus has wringed hands, but the gesture of John is different. He rises his hands like orant to the crucified Christ. This is the gesture of the prayer but in this connects it could be the gesture of testimony. John is present at the cross as a witness of the death of Christ and of the fulfilment of the salvific project.

St John as a witness of the Christ is present in the miniature of Crucifixion in the Missal of Wilhering (Wilhering, Stiftsbibliothek, n. 9) ${ }^{14}$. He hold the book taking it by the tissue of his cloak. This gesture, full of reverence and respect means that John, holder of the Gospelis the ocular witness of the divinity of Christ. The presentation of the book we constates in the miniature in the Missal of Sigmund Knabe (Bmo, MA 12/9, 149v) $)^{15}$.

"V. Mende, A. und L. Hirmer, Die Bronzetfiren des Miitelalters, Munchem 1983, p. 76, il. 111.

${ }^{12}$ Der Landgrafen psalter: Ein Bilderhandschrift aus dem Anfang des XIII Jahrhunderts In der Würtembergischen Landesbibliothek, mit Einleitung von K. LOfler, Leipzig 1925, fol. 73v.

${ }^{13}$ D. Tabor, lluminacje cysterskich kodeksów slaskich XIII wieku, Kraków, p. 82-83, il. 65.

${ }^{14}$ A. Karlowska-Kamzowa, Malarstwo gotyckie Europy Środkowo-Wschodniej: zagadnienie odrębności regionu, Warszawa-Poznań 1981, il. 130.

${ }^{15}$ Déjiny Českèho vílvarnèho umèni, I/2, s. 420-421, il. 68. 


\section{B. DESCENDING INTO THE HELL}

The miniature Descending to $\mathrm{Hel}$ represent Christ wearing the blue tunic and red cloak who strides to the open mouth of the monster ${ }^{16}$. From this mouth go out the nude figures - the saved predecessor. Christ approach to them. Two gesture has a great importance: the holding of a stab and taking band of the nude. The stab with a flag is the antic symbol. Labarum - the flag revealed to the emperor Constantin, was described by Eusebius in "Vita Constantini", as a sign of a future victory. The stab with banner, vexilium was an attribute of the victorious commander. Christ $b$ holding the flag is describe as a conqueror, who had broken the hell' $s$ gate and deliver the slaves.

Christ take the band of first man - Adam. This gesture, taking by hand has a biblical source. There are three situation in the gospel of Mark, when Jesus takes someone by hand and deliver from the demon's possession, heals and revives. This is the haling of Peter's mother-in-law (Mk1, 29-31), the revival of the daughter of Jairus (Mk 5, 21-43), delivering of a possessed boy(Mk 9, 14-29).

Descending into Hen is the topic of the Ancient homily on Holy Saturday (Patrologia Graeca 43, 440-464). Christ comes to search first parent. He approaches bearing the cross and takes Adam by hand. This events are interpreted as a prophetical signs of a future salvation. In alt this situations Jesus uses significant gesture. In the conclusion of the miracle's processing he takes the person by hand. This means that Christ as saviour saves this person. In the representations of Descending into the Hell the taking by hand means that the work of salvation was complied.

\section{THREE WOMAN WITH ANGEL AT THE TOMB}

On the miniature in Psalter from Trzebnica (Wroclaw, The University Library, IF 440, 98r) presents the open sarcophagus, three sleeping guards, three women and sitting angel (fig. 7) ${ }^{17}$. Women are confused. Two of them are telling one with another. Third women stretch his hand to angel. He shows them the wrap taked from the tomb.

The similar miniature is in the Antifonar from Sedlec (Bohemia) (Praha, University Library, XIII A6, 173r $)^{18}$. Women who hold the phials heard the angel who shows them the crumpled wrap. Gestures of women are full of reserve, uncertainty and anxiety. This iconographical type was inspired by the text of Gospel. One angel is mentioned by Matthew - "...angelus enim Domini descendit de caelo..." $(\mathrm{Mt} 28,2)$. The message of angel who points the tomb and invites the women to see the place of this deposition is includen in Gospels of Matthew and Marc:

${ }^{16}$ Der Landgrafen psalter.., fol. 92r.

${ }^{17}$ D. Tabor, Iluminacje, p. 83, il. 69.

${ }^{18}$ Déjiny českého výtvarnèho umèni, $\mathrm{I} / 1$, s. 116-117, il. 20. 
“... venite videte locum ubi positus erat...” (Mt 28, 6), “...ecce locus ubi posuerunt eum..." (Mk 16, 6). The wrap however was described by John - "...et sudarium quod fuerat super caput eius... sed separatim in volutum in unum locum..." (Jn 20,7). Sudarium - the wrap which has been taked by angel is the evidence of the resurrection of Christ. The gesture of angel - taking or pointing this wrap is the focal point of this representation. The resurrection - mysterious and hidden event bas been expressed by this significant gesture, because angel shows its principal evidence.

The representation from the altarpiece from Vysebrod (Hochenfuhrt) (Prag, National Galerie) unifies in simultaneity two images - Three women at the tomb and Resurrection ${ }^{19}$. In the first the angel sitting in the open sarcophagus shows to women the wrap, but the dominating figure is Christ in the moment of leaving the tomb. This figure from beginning of XIV century contains the meaning of the Paschal Mystery

\section{IMAGE OF THE RESURRECION}

The altarpiece from Vyšsi Brod (Hochenfuhrt) (Prag, National Galery) presents Christ wearing majestic garment - tunic and cloak just in the moment in which he surpass the border of the sarcophagus (fig. 8) ${ }^{20}$. His position is majestic, his face severe. He keep in his left hand the stab with banner - vexilium. The right hand is raised and the palm with two fingers is exposed. This gesture come from the iconographical type Maiestas Domini. Christ sitting in the majestic pose rises his hand with two fingers. This image most popular in the monastic communities, especially in the congregation of Cluny. His origin there is in ancient rhetoric, when the gestures of hand was the middle of communication. The gesture of raised hand with two fingers is the gesture of blessing in the liturgy. It token double feature - greek blessing and latin blessing ${ }^{21}$. Christ presented in the couple of absis is the High Priest.

Is the gesture of the Christ going out of the tomb the sign of the blessing? The answer we can find in the internal disposition of elements of the representation. This representation is the visualization of a mysterious event - Resurrection. His sense consists in three oppositions. This is opposition between verticality of Christ and levelness of the tomb, the contrast between vitality of Christ and sleeping guards, the contrast between inertion and gravity of the sarcophagus and he character of Christ - full of power, majesty and dynamism. The Risen Christ from the quarter of retable from Trebon is lifted upon the heavy tombstone ${ }^{22}$. This contrast between figure of Christ and the close sarcophagus has been got stronger. Christ

\footnotetext{
${ }^{19}$ A. Matěkcek, J. Pešina, Goishe Malerei in Böhmen, p. 49-50.

${ }^{20}$ Ibidem, p. 49-50.

${ }^{21} \mathrm{M}$ Barassch, Giotto and the language, p. 17-19.

${ }^{22}$ A. Matějček, J. Pešina, Gotische Malerei in Böhmen, p. 61.
} 
who goes out the tomb is the extraordinary person: he is conqueror of the death. It had been showed by the opposition, especially by the opposition between sleeping guards (sleep as a symbol of the death) and living Christ. In this contest the raised hand with two fingers reveals his sense. We find this gesture in the type of Maiestas Domini. Christ in this representation rules rather death and devil than the universe symbolized by four creature. This gesture, recognized as a "latin blessing" in this context became the sign of power, domination.

He dominate the death, symbolized by tomb and sleep. The entire figure of Christ expresses the strength, power and might. All characteristics of the Risen have been synthetised in the gesture of two fingers. The second gesture, the holding of the banner takes up the new and profound meanings, because the flag is marked by the sign of cross. It takes its origin from labarum of the sarcophagus of Passion from Vatican Museum. This is symbol of the Resurrection of Christ. The banner with cross refers to the representation of the Lamb, magnificent symbol of Apocalypses (Ap 5, 5-14). The Lamb, killed but living is personification of the suffering, death and victory of Christ. Besides The flag signed by cross is guaranty of identity of Saviour. He is the same who descended into the Hole in order to liberate the predecessor. Therefore, the gesture of exposing the banner in this context don't reveals the victory, but rather is testimony of the Passion and the death.

In the general sense of the visualization of the resurrection we discover the conflict between Christ - man and God and Death and Demon. This metaphysical conflict is marked by banner with cross (suffering and death) and by the gesture of latin blessing (domination upon the world of death and tenebrous). The idea of the conflict came from the famous liturgical text - a sequence Victimae Paschali laudes composed by Wipo ( $\dagger 1046)$. It is said:

"Mors et vita duello cornfixere mirando :dux vitae ortuus regnat Vivus"23.

In the conclusion of this text Christ is definited as rex victor. It is the most precise characteristic of the protagonist of this scene.

\section{ASCENSION}

The Miniature of Ascension from Landgrafenpsalter present Christ ascending upon the hill accompanied by two angels ${ }^{24}$. Around the hill stand the disciples and his Mother. Everyone raises the eyes to Jesus, who exposed in the majestic, hieratic pose hold the stab with banner in the left hand and points down the right hand with two fingers. This same scheme we constate in the miniature of Ascension in the Psalter of Trzebnica and in the Brandemburger Evangelistar ${ }^{25}$. In this representa-

${ }^{23}$ Officium et Missa In die Paschae, [in:] Liber usualis missae et officii pro dominicis et festis cum canto gregoriano. Parisiis Tornaci Roman Neo Eboraci 1958, p. 780.

${ }^{24}$ Der Landgrafenpsalter, fol. 109v.

${ }^{25}$ D. Tabor, Iluminacje, il. 72, 178. 
tion three gesture bring out the meanings,(contents). The holding of the stab marks Jesus as conqueror. This gesture underline his character as a victorious dominator of death, an identify him as same who descended in the Hole and has gone out of the tomb. The right hand makes a gesture which is similar as a gesture of two fingers-latin blessing in the image of the Resurrection. However this movement is modified. Jesus doesn't rise the hand up, but points two fingers down. This motion contrasts the movement of heads of the disciples and Mary. This opposition evokes the last dialogue of Christ and the imposition of the mission. The Gospel of Matthew mention the mission: "Euntes docete omnes gentes baptizantes eos in nominee Patris et Filli et Spirutus Sancti" (Mt 28, 19), so Marc too (Mc 16, 15-16). The Gospel of Luke underlines the blessing: "...eduxit autem eos foras in Bethaniam et elevates minibus suis benedixit eis et factum est dum benedixit eis et factum est dum benediceret illis recessit ab eis..." (Lc 24, 50-5I).

What aspect of meaning is highlighted in this complexity of gestures - last blessing or imposision of the mission? Because Jesus is raised upon the hill, we can constate that this representation shows the blessing of apostles in the moment of Ascension.

\section{TRINITY - SOURCE AND FULLFILLMENT \\ OF THE MYSTERY}

The painted table found in the Church of Swiezawa in Silesia shows us the God Father, sitting in the architectonical throne and wearing the ceremonial garment (fig. 9). He holds the cross with the hanging, crucified Jesus. God Father in frontal pose exposes the Son, who is dying in the cross. The element which let to interpret this situation is the gesture of God Father. He present his Son to the World ${ }^{26}$.

The concept of Sedes Gratiae (Throne of grace) comes from the Epistle to the Hebrews. Christ is proclaimed the High Priest who offered himself to God for the redemption and entered in the sanctuary with his own blood.

"Christus autem adsistens pontifex futurorum bonorum per amplius et perfectius tabernaculum non manufactum..., sed per proprium sanguinem introivit semel in sancta aeterna redemptione inventa..." (Reb 9, 11-12).

The sacrifice of Christ was accepted by Father and now he is exposed as compassionated High Priest. Throne of God in this moment became the throne of grace(Heb 4,16$)$. The gesture of father, gesture of two hands is necessary to understand the priesthood of Christ. The Pascal Mystery is described as the entering of Christ in the heavenly sanctuary by suffering and death.

${ }^{26}$ A. Ziomecka, Malarstwo tablicowe na Ślqsku, [in:] Malarstwo gotyckie w Polsce, 1: Synteza, ed. A. S. Labuda i K. Secomska, Warszawa 2001, p. 216-217, il. XC. 
The table which is part of the retable from St Mary Church in Torun represents the Trinity (fig. 10) ${ }^{27}$. In the center of the image there is the cross - tree of life. To the cross is fixed Christ, but his figure is covered with veil. Branches of tree make the medallions (tondos), in which there are for apocalyptic animals and bellows the lamb fixed to the tree. In the oval frame, connected with the tree of life seats the God Father with little Jesus. Below the cross at right stands st John the Baptist and kneels Ecclesia who collect the blood of the Lamb to the chalice. At left there are Synagogue and the woman with he Eucharistic chalice. The oval frame is flanked by four angels, two of every side. Angels bend down kneeling from and have folded hands.

This structure is reach of meanings. The veil which covers the crucified is mentioned in the Epistle to the Hebrew (Heb 9, 3). Christ as the High Priest has entered in the sanctuary beyond the veil holding his own blood (Heb 9, 24). The lamb fixed to the trunk of the cross bas his source in the Apocalypsis. The vision of the lamb in the 5th chapter, in context of the heavenly celebration represents the victorious Christ (Ap 5, 6-8). The God Father who sits on the arc in the oval frame shows the majesty and power. The little figure whom he hold, is Christ-Logos, Son of God preexisting before Incarnation. These are the principals protagonists of this image. They represent the Trinity, but because the Son of God is presented thrice, Tadeusz Dobrzeniecki calls it "Quinitas"28.

All person in this magnificent vision make the gesture. Christ-Logos sitting on the womb/breast of Father raises the right hand with two fingers in the "latin blessing" and puts his left hand in the sphere. Even he is minimized and joined with Father he appears as a person full of power and dominator who participates in the Creation - hand put in the sphere. God father points down the right hand and directs it to the angel. This gesture discover the decision of the Trinity - the Incarnation of the Son. The situation below the cross and below the oval frame demonstrates the consequences of this decision. The central person is the lamb fixed to the frame. Ecclesia kneeling in adoration touches his face with the left hand. This gesture underlines the meditation and adoration, reflection about the death of the Lamb - Christ. In the right hand she holds the chalice in which she collects the blood flowing out the lamb's injury. His blood becomes the precious and uncovers the Eucharist as a sense of the lamb's death. At left of the round frame kneels the second female figure - Synagogue. She turns away from the Lamb and holds in her left hand the goat's skull. His attitudes shows incredulity and impossibility to recognize the meaning of events.

${ }^{27}$ A. S. Labuda, Malarstwo tablicowe na Pomorzu Wschodnim, [in:] Malarstwo gotyckie w Polsce, 1: Synteza, p. 334, il. XCII.

${ }^{28}$ T. Dobrzeniecki, The Torun Quinity In the National Museum in Warsaw, [in:] The Art Bulletin XIVI(1964), vol. 3, p. 380-388. 
Saint John the Baptist who stays at right points with the finger the Lamb and says: "Ecce agnus dei qui tollit peccata mundi" $(11,29)$. The woman at left hold the Eucharistic chalice with the host. Both figures play the indispensable role. They recognize the true character of the Lamb. He is prefiguration, the image. John and woman with chalice declare him as a Savior.

The Lamb as central protagonist of the paschal Mystery was meditated by Meliton, bishop of Sardes, He underlines the passing from the prefiguration to the reality, from the ancient law to the Gospel ${ }^{29}$. Orygenes in his sermon on Genesis analyses the Jewish pasha and the sacrifice of the lamb from the beck of Exodus and find than the meanings of Christian Easter (Patrologia Graeca 12, 203-210). The lamb sacrificed is mentioned in Exultet ${ }^{30}$. Therefore, all figure who join with Lamb in our representation are involved in the procedure of interpretation of the central symbol and in the economy of announcement and realization. This symbol is surrounded by gesture - pointed finger of John, risen chalice of woman, turned face of Ecclesia, Synagogue and exposed chalice in the hand of woman definite the identity and explain the sense of lamb.

\section{COCNLUSION}

There are two ways of the presentation of the Paschal Mystery in the central European art: presentative way and narrative way. These ways aren't contradictories but they are complementary to one another mutually. The presentative way exposes the situation to meditation and contemplation. The narrative way exposes the series of images and introduces the viewer in the dynamic process with initiation, conflict, culmination and conclusion. In both ways the gesture is indispensable medium of expression. Its role can be described as an integrative symbol and a key. Integrative symbol, which joins different elements of the images, connects and arrange the different sectors of meaning. The key makes all the contents and meanings accessible for the viewer, opens different layers of the paschal message and let us understand this message.

The gesture as expression of the Paschal Mystery is fascinous topic. The research on this matter to be continued.

${ }^{29}$ Meliton, Homélie sur la Pâque, [in:] Soprces chretiennes $123,60-64,120-122$.
${ }^{30}$ Dominica Resurrectionis: De vigilia paschali, [in:] Liber usualis, p. $776 \mathrm{~N}-7760$ 


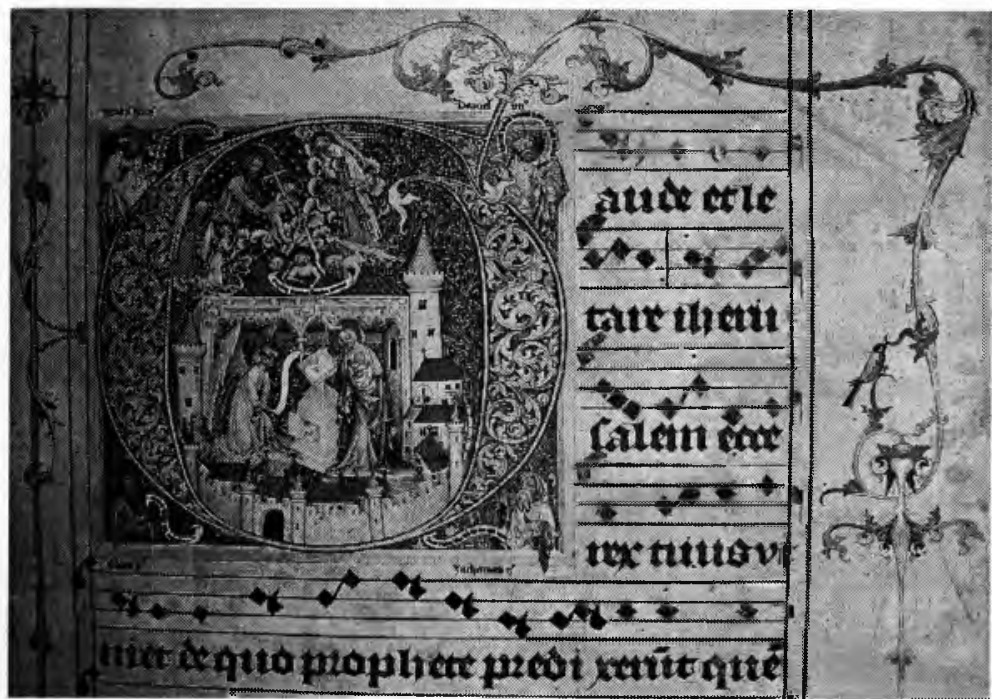

Fig. 1. Initial G(aude et letare $)$ - God the Father sending Christ into the Earth/ Annunciation, Matutinale et Vesperale, Zitava, Augustinian Church

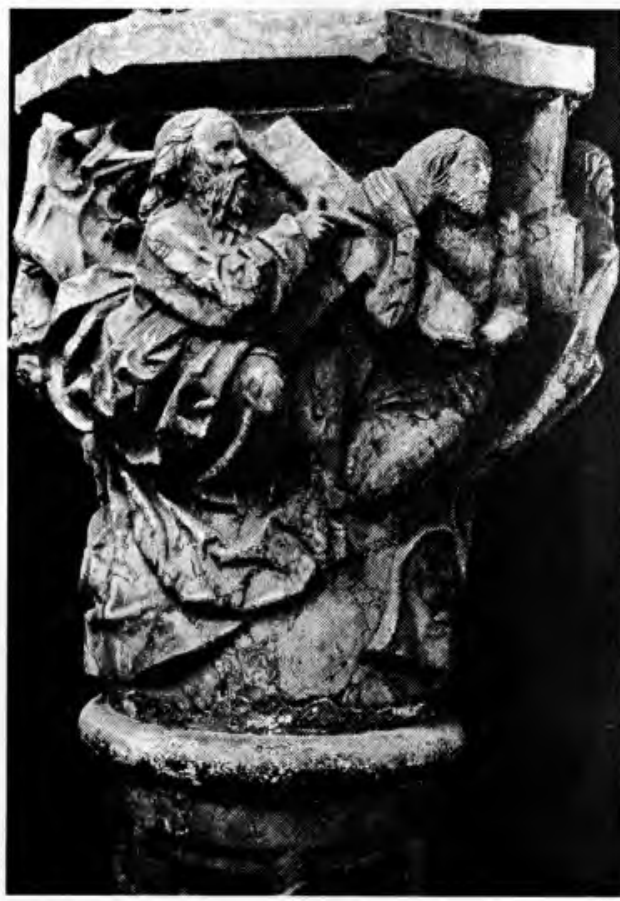

Fig. 2. God the Father imposing the cross into the shoulders of Christ - chapiter of column from the tomb of the King Casimire, by Veit Stoss and Jorg Huber, Cracow, cathedral, 1492 

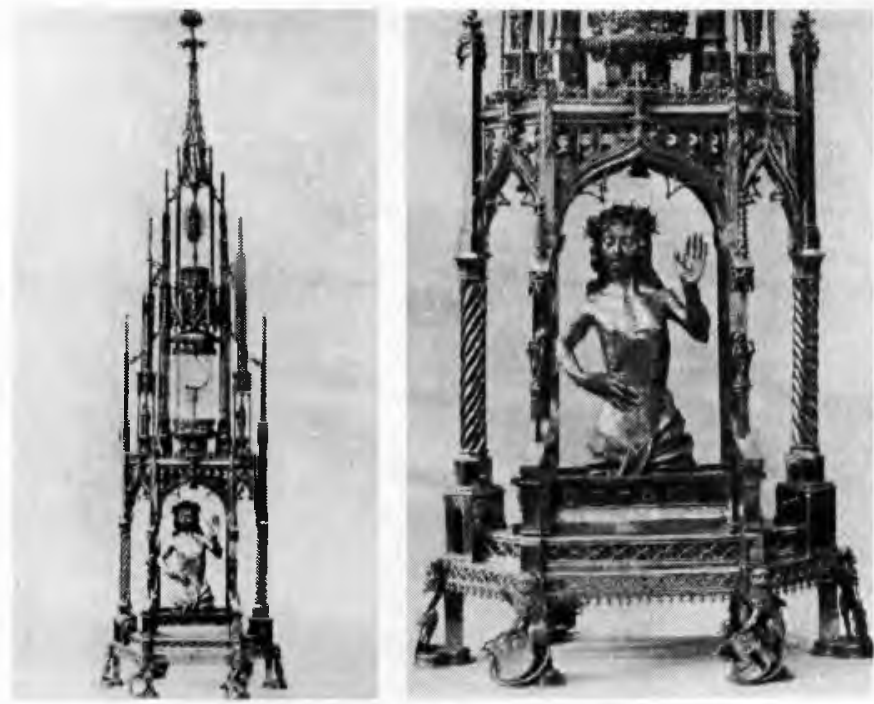

Fig. 3. The ostensory with the figure Man of Sorrow, Racibórz (Ratibor), 1495

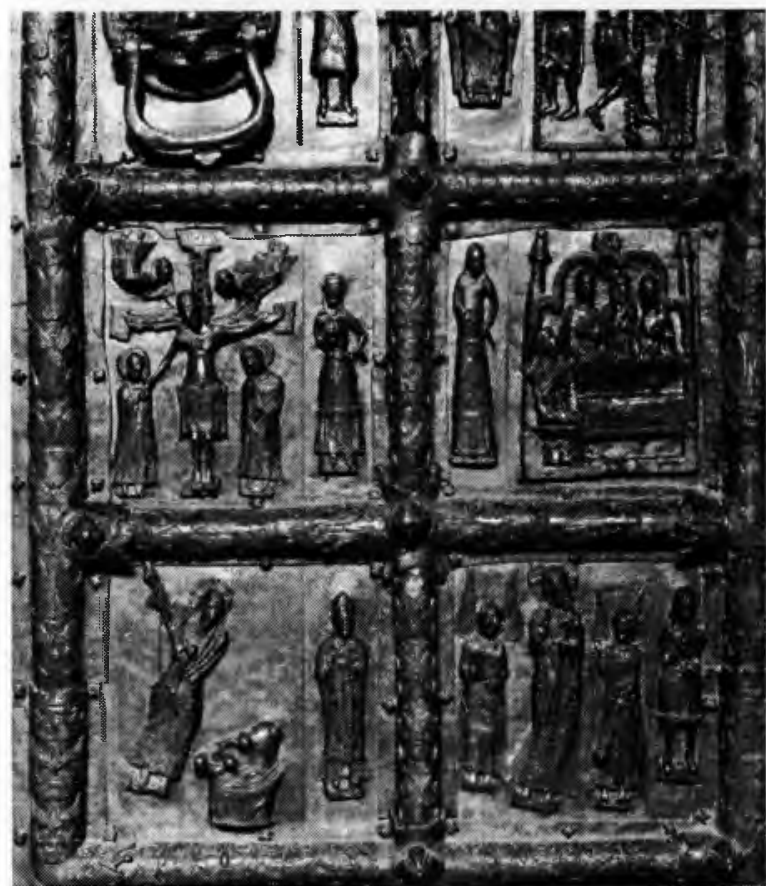

Fig. 4. Crucifixion of Christ, Deposition into the tomb, Descending into the hell, Ascensionquarters from the bronze door of Plock, 1165-1167 
Gesture as the Expresion of the Pascal Mystery...

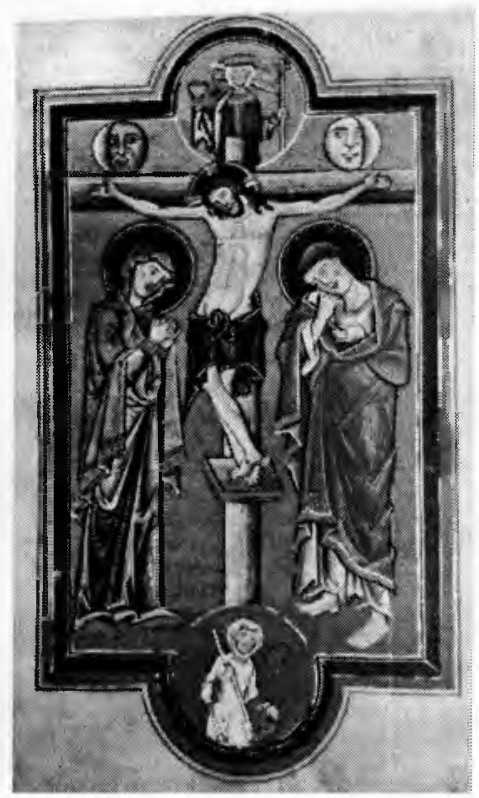

Fig. 5. Crucifixion - miniature from the Landgrafenpsalter, $1211-1213$

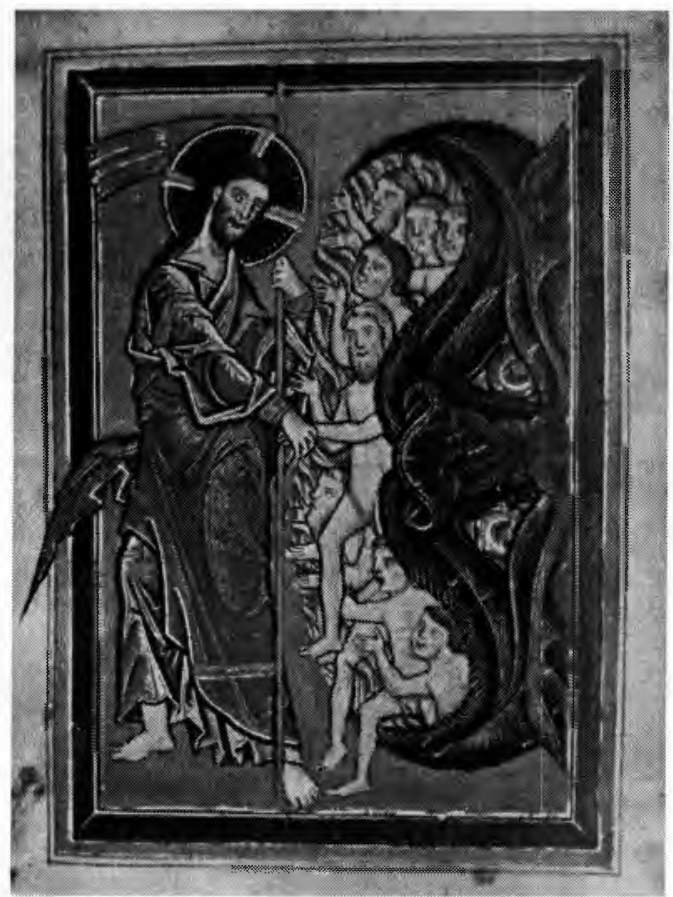

Fig. 6. Descending into the hell-miniature from Landgrafenpsalter, 1211-1213 


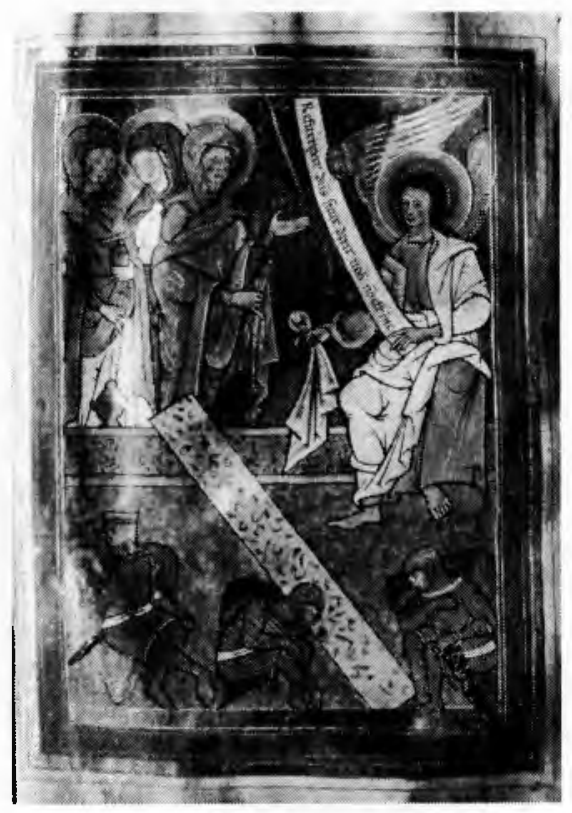

Fig. 7. Women visiting the tomb - miniature from the Psalter of Trzebnica, 1238-1245

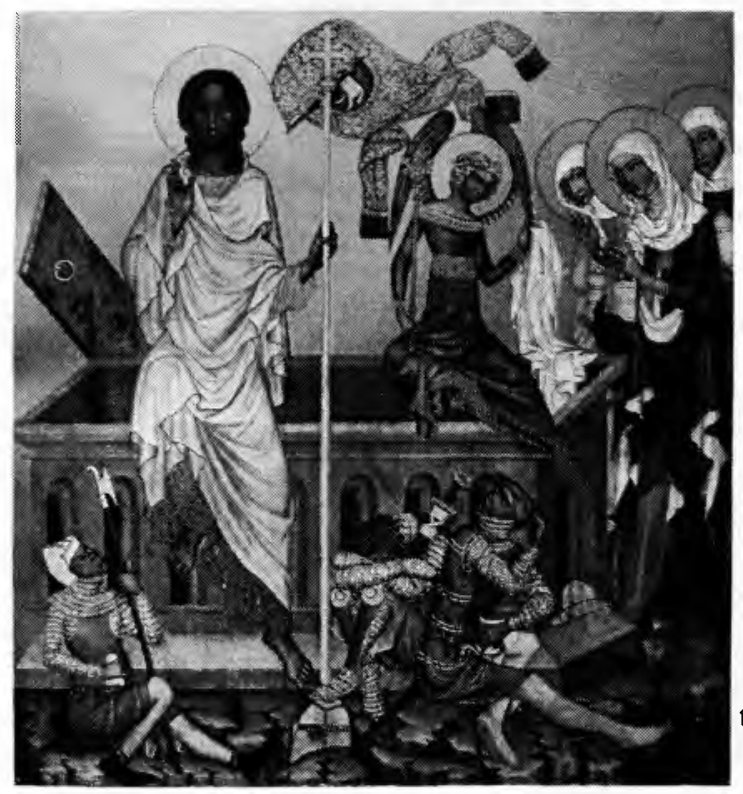

Fig. 8. Resurrection of Christ and Women visiting the tomb - quarter from the retable of Vyšši Brod (Hohenfurth), about 1350-1390 

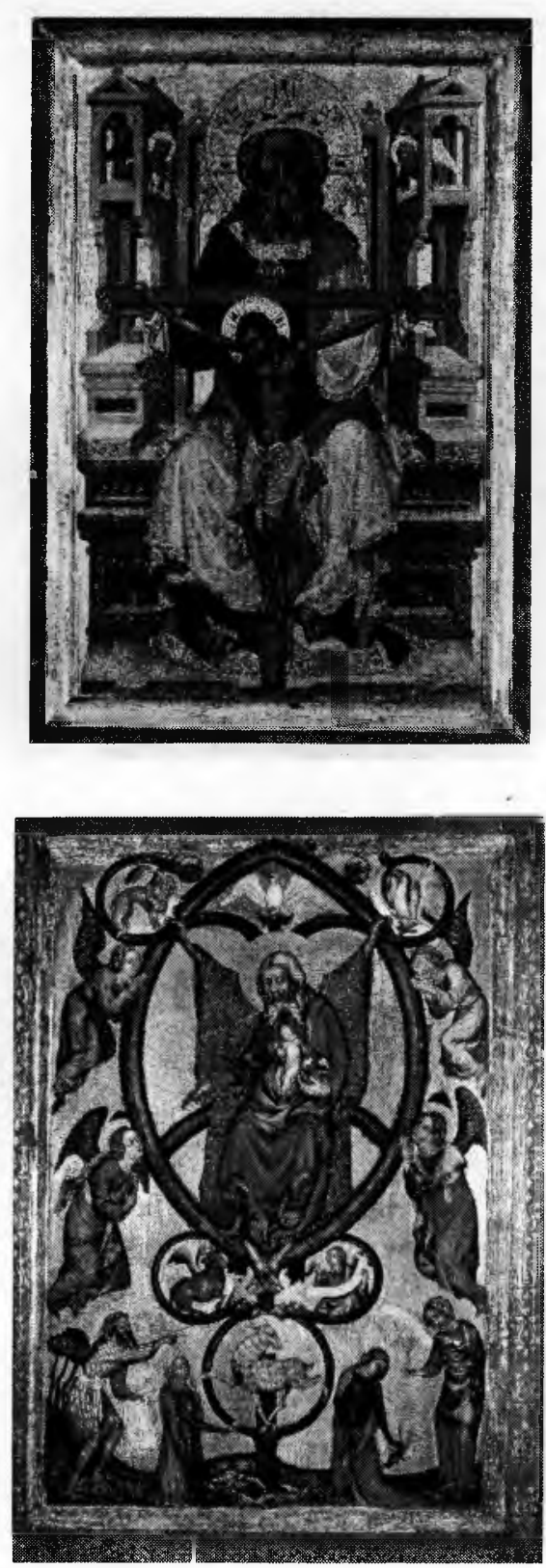

Fig. 9. Trinity - Sedes Gratiae - table from Swieżawa, Silesia, about 1350
Fig. 10. Trinity - Quinitas, table from the Franciscan Church, Torun, about 1360-1390 